\title{
Essentials to kill the cancer
}

\author{
Rachana*, Kritika Sehgal and Manisha Singh \\ Department of Biotechnology, JayPee Institute of Information Technology, India
}

Submission: April 25, 2017 ; Published: May 02, 2017

"Correspondence Address: Rachana, Department of Biotechnology, JayPee Institute of Information Technology, Noida, Sector 62, Noida, UP 201307, India, Email: rachana.dr@gmail.com

\begin{abstract}
Essential oils are the secondary metabolites produced by a variety of plants which are utilized in their various basic physiological and ecological processes. Essential oils (EOs) have been used throughout the world for various applications such as: cosmetics and religious purposes. India and many other countries have history of using them for their medicinal properties as well. These oils are produced in a very minimal amount by the plants, also they get evaporated during the extraction and so the cost of the oils may increase with the quality and purity. EOs have been utilized to treat various common symptoms like pain relief, cold and cough to the fatal disease like cancer. The major components of EO include: terpenoids, alkaloids and phenolic compounds etc. and very often the therapeutic potential of EO are referred to the combinations of various above different types of molecules present in different quantities and not the single compound. Various compounds in the mixture have been isolated and have been researched upon for the anti cancer properties, separately but most of the time the efficacy of the pure compound has been found be very much low than the crude combinations. Various mechanisms have been suggested for the anticancer properties of EOs including induction of apoptosis and suppressing inflammation. They have been reported to have IC50 as low as $\sim 1 \mu \mathrm{g} / \mathrm{ml}$ to few $\mathrm{mg} / \mathrm{ml}$ which depends upon the plant source and also the cancer targeted. Major problems faced with the widely accepted chemotherapy for cancer is, the side effects associated with it, which includes nausea, anxiety, pain etc. and EOs are known for the anticancer as well as, for their effect on the psychology of the patients who are going through these painful therapies. The present review focuses on few commonly used plants such as: Rose, Mari gold, Ginger, Rose merry, Brazilian pepper, Lemon grass, Basil, Black cumin etc for the anticancer properties of essential oils with the latest development in.
\end{abstract}

\section{Introduction}

Cancer is prevailing in all the parts of the world now. It's not only a disease of rich people in urban areas. People in rural areas are equally affected by this deadly disease. The main reason is that also though they don't follow the life style of the urban people they are more exposed to habits like smoking, insecticides pesticides, low hygiene etc. They are also not aware what how they are putting themselves in danger of causing these kind if diseases. Smoking is common in urban and rural both areas but the people from village use cheap mean for the same which more harmful. They get exposed to pesticide and insecticide while working with them in field. They don't even take precautions while using these kinds of chemicals as they are not aware of it. It that's why becomes more important to have cheaper medicines to treat such diseases. The cancer therapy available these days is highly expensive and less likely to be accessible to the poor people. Other than this as it a well known fact that even the most expensive drugs for cancer are becoming outdated as the cancer cells are becoming resistant to the drugs, so there is always a thrust to discover new medicine to treat cancer. One more important thing is also to be mentioned is that the chemotherapy which is believed to be the best these days has enormous side effects and don't have patient compliance at all. Considering all these facts plant based medicines are being explored to a large extent throughout the world. It's not that these have been tried now but in fact best chemotherapeutic drugs have like paclitaxel etc. have been derived from plants only. This ways plants remained the most important source of these medicines. It is interesting to note that the diet structure we have seems to be planned very intelligently which includes so many anticancer agent in our daily life. The present review is an attempt to explore few of such plants which in daily use and also has anticancer activities.

\section{Rosa damascena (Rose)}

Rose, scientifically known as Rosa damask or Rosa damascena belongs to the Rosaceae family. It can be found in various countries, including Bulgaria and India [1]. The essential oil from rose is commonly known as attar of rose or rose essence [2]. The essential oil is extracted from the rose petals through various methods like steam distillation or solvent extraction, depending on concentration needed [3]. Rosa damascena mill $\mathrm{L}$ is the most commonly used rose species. It had been showed to exhibit various properties such as; antitussive, anti-HIV, antioxidant, antibacterial, hypnotic, antidiabetic, and relaxant for trachea. Phenolics, which are abundantly present in rose, have many pharmacological activities, such as antioxidants, anticancer, anti-inflammatory, free-radical scavengers antimutagenic, and antidepressant [4]. Terpenes, flavonoids, 


\section{Cancer Therapy \& Oncology International Journal}

glycosides and anthocyanins are present in the plant [1]. Various compounds in Rose essential oil which included $\beta$-citronellol, nonadecane, geraniol, hose quantities varied from $14.5-47.5 \%$, $10.5-40.5 \%$ and $5.5-18 \%$, respectively. Major components of the oil included nerol and kaempferol. Rose essential oil was investigated by Hotta et al. [5] for its anticancer properties. Bovine arterial endothelial cells in cell-based transfection assays showed suppression of COX-2 promotor activity. The expression of COX-2 is important for inflammation and circulatory homeostasis [5]. Reported IC50 values were as low as $13.03 \pm$ 0.8 and $16.44 \pm 1.4 \mu \mathrm{g} / \mathrm{mL}$ for cancer cell lines HepG2 (Liver) and MCF7 (human breast cancer) respectively, when checked for anti-cancer properties [6].

In another study by $\mathrm{Zu}$ et al. [7], three cancer lines, namely, A-549 (human lung carcinoma), PC - 3 (human prostate cancer cell lines) and MCF-7 (breast cancer cell line) were treated with $100 \mu \mathrm{l}$ liquid rose essential oil dilutions from $0.200 \%$ to $0.002 \%$ (v/v) and their anti-cancer activity was measured by MTT assay. At Inhibition concentrations of $50 \%$, IC50 values of $0.040 \% \mathrm{v} / \mathrm{v}$, $0.055 \% \mathrm{v} / \mathrm{v}$ and $0.074 \% \mathrm{v} / \mathrm{v}$ were obtained for PC- 3, A-549 and MCF-7 cancer cell line respectively [7]. These indicate that rose can be used to derive anticancer medicine against Liver, Breast, Prostate cancers. There are many more studies which explore the mechanism of action of rose. Geraniol is one of the main components of rose which has been reported to work through various mechanisms such as induction of apoptosis as it increases the expression of apoptotic protein Bak and arrests the G0/ G1 phase of cell cycle. It also reduces cdk2 activity and inhibits the 3-hydroxy-3-methylglutaryl-CoA (HMG-CoA) reductase and ornithine decarboxylase activity. All these activities combonely lead to the death of the cancer cells.

\section{Zingiber officinale (Ginger)}

Ginger, scientifically known as Zingiber officinale, belongs to the Zingiberaceae family [8]. It is majorly produced by China and India. The oil has a spicy aroma because of presence of ketones. It is extracted from the oily resin from ginger's roots, which contains various bioactive components, like 6-gingerol (1-[4'-hydroxy-3'- methoxyphenyl]-5-hydroxy-3decanone [8]. Ginger essential oil has been known in preventing joint inflammation and destruction since long [9]. Its main constituents include eucalyptol (14.2\%), cuparene (12.3\%), bicycloheptane $(11.4 \%)$ and $\gamma$-muurolene $(10 \%)$ as measured by GC-MC analysis (Ref:1). Zu et al. [7] studied cytotoxic effect of Ginger essential oil on few cancer lines, which included MCF-7 (breast cancer cell line), A-549 (human lung carcinoma) and PC3 (human prostate cancer cell lines). These were treated with $100 \mu \mathrm{l}$ liquid rose essential oil having dilutions from $0.200 \%$ to $0.002 \%(\mathrm{v} / \mathrm{v})$ and their anti-cancer activity was measured by MTT assay. At Inhibition concentrations of 50\%, IC50 values of $0.077 \% \mathrm{v} / \mathrm{v}$ and $0.107 \% \mathrm{v} / \mathrm{v} \mathrm{v}$ were obtained for PC- 3 and A-549 cancer cell line respectively. However, no cytotoxic effect was observed on MCF-7 cancer cell line [7]. Ginger oil has exhibited strongest anti-cancer activity against endometrial cancer cell line Ishikawa and ECC- 1 with IC50 of $1.25 \mu \mathrm{g} / \mathrm{ml}$, mediated by apoptosis by activating p53 [10].

\section{Ocimum basilicum (Basil)}

Basil, also known as Ocimum basilicum belongs to the Lamiaceae family and is native to Iran and India [8]. Its main constituents include eugenol, isoeugenol and linalool. In a cell line study, basil oil showed antiproliferative activity with an IC50 value of $0.0362 \mathrm{mg} / \mathrm{mL}$ in P388 murine leukemia cell line and a value of $0.3033 \mathrm{mg} / \mathrm{mL}$ in $\mathrm{KB}$ human mouth epidermal carcinoma cell line, using MTT assay. It also inhibits the cell proliferation induced by PDGF (platelet-derived growth factor) or tumor necrosis factor- $\alpha$ [11] in cultured murine mesangial cells in which cell line. In another study conducted by Kathirvel et al. [12] the constituents of Basil essential oil were investigated to be, linalool, $\beta$-elemene and camphor methyl cinnamate to be $17.50 \%, 2.60 \%, 1.52 \%$ and $70.10 \%$, respectively. MTT assay was conducted to study in vitro cytotoxicity against the HeLa (human cervical cancer cell line, NIH 3T3 mouse embryonic fibroblasts and HEp-2 (human laryngeal epithelial carcinoma cell line). The IC50 values obtained were $90.5 \mathrm{mg} / \mathrm{mL}, 120.7 \mathrm{mg} / \mathrm{mL}$ and 96.3 $\mathrm{mg} / \mathrm{mL}$, respectively, and this revealed that basil oil can be used as a therapeutic drug against cancer (Kathirvel and Ravi, 2012).

\section{Tageteserecta (Mexicanmarigold)}

Scientifically Mexican marigold is known as Tagetes erecta and belongs to the Asteraceae family. Its essential oil is derived from the flower petals [13]. Its major constituents include cis$\beta$-ocimene, cis-tagetone and trans-tagetenone cistagetenone dihydrotagetone and limonene present in 54.82\%, $11.50 \%$, $10.78 \%, 7.10 \%, 6.50 \%$ and $3.82 \%$, respectively, as mentioned by Mahmoud [14]. The anticancer activity was checked on human promyelocytic leukaemia cell lines HL-60 and NB4 and experimental animals model cancer cell line (EACC) were investigated in vitro. Marigold essential oil had high anticancer activity against NB4 and EACC than HL-60 cell line. At a concentration of $200 \mu \mathrm{g} / \mathrm{ml}$, viable cell \% of HL-60, NB4 and EACC cell line were $37.89 \%, 18.13 \%$ and $0 \%$ respectively [14]. In a study conducted by Alve et al. (2015), various cell lines including human hepato cellular liver carcinoma (HepG2), tumour cell lines murine melanoma (B16F10), human breast adeno carcinoma (MCF-7), human cervical adeno carcinoma (HeLa), human glioblastoma (U343, M059J, and U251) and human colon carcinoma (HT29) were treated with Tagetes erecta essential oil. Some of the noticeable cell line corresponding to their IC50 value included V79- $19.50 \pm 5.96 \mu \mathrm{g} / \mathrm{ml}, \mathrm{B} 16 \mathrm{~F} 10-7.47$ $\pm 1.08 \mu \mathrm{g} / \mathrm{ml}, \mathrm{HT} 29-6.93 \pm 0.77 \mu \mathrm{g} / \mathrm{ml}$, HeLa- $26.02 \pm 5.52 \mu \mathrm{g} / \mathrm{ml}$, M059J- $38.69 \pm 5.51 \mu \mathrm{g} / \mathrm{ml}$. However, the lowest IC50 values were obtained for B16F10 cells $(7.47 \pm 1.08 \mu \mathrm{g} / \mathrm{ml})$ and HT29 cells $(6.93 \pm 0.77 \mu \mathrm{g} / \mathrm{ml})$ [13].

\section{Rosmarinus officinalis (Rosemary)}

Rosemary, scientifically known as Rosmarinus officinalis belongs to the Lamiaceae family. Rosemary belongs to the 


\section{Cancer Therapy \& Oncology International Journal}

Mediterranean region [8]. These shrubs have needle like leaves, and have been used for pest control and flavouring agents. Rosemary oil's main constituents include p-cymene, linalool, gamma-terpinene, thymol, beta-pinene, alpha-pinene and eucalyptol as reported by Özcan and Chalchat [15]. As reported by Wang et al [16], when human ovarian cancer cells SK-OV3 and H0-8910 were treated with Rosemary essential oil at concentrations from $0.0625 \%-1 \%$, inhibited cell viability was observed at an IC50 value of $0.025 \%$ and $0.076 \%$ in each cell line respectively after 48 hours. Cell viability was inhibited in Bel-7402 liver cells at an IC50 value of $0.13 \%$ at a concentration of $1.3 \mathrm{mg} / \mathrm{mL}$ after 48 hours as mentioned in the blog (Ref:2).

\section{Cymbopogon citratus (Lemon grass)}

Scientifically, lemon grass is also called Cymbopogon citratus . It can be found in countries like India, Africa and Australia etc [17]. The essential oil of Eastern lemon grass, or scientifically known as Cymbopogon flexuosus, has been shown to have cytotoxicity in neuroblastoma (IMR-32), liver (Hep-g2), colon (502713), and cervix (SiHa) cell lines, which depends on dosage. The reported IC50 values range from 4.2 to $6.5 \mu \mathrm{g} / \mathrm{mL}$. This lemon grass oil also induced growth inhibition, decreased the ascitic fluid volume, and total ascites cell number in solid and ascitic Ehrlich and S-180 tumor models in mice [17].

HL-60 Leukemia cancer cells treated with lemongrass essential oil lost their surface projection, thus losing normal cell function. Isointermedeol which is a sesquiterpene present in the oil was attributed for a good IC50 value of $30 \mu \mathrm{g} / \mathrm{mL}$.Colon and Neuroblastoma cancers were the most susceptible to Lemongrass treatment. Citral is known to induce apoptosis in liver cell line as mentioned in the blog (Ref:2).

The essential oil from a lemongrass variety of Cymbopogonflexuosus (CFO) and sesquiterpene isointermedeol (ISO), which is its main component, were checked for their ability to induce apoptosis in HL-60 cells (human leukemia), because deregulation of apoptosis is the trademark of cancer cells. Cell proliferation was inhibited by CFO and ISO and had an IC50 of $30 \mu \mathrm{g} / \mathrm{ml}$ and $20 \mu \mathrm{g} / \mathrm{ml}$, respectively [18]. The essential oil from C. citratus and its isolated principal citral have been tested for cytotoxicity against P388 leukemia cells. The cytotoxicity of citral against P388 mouse leukemia cells had an IC50 value of $71 \mu \mathrm{g} / \mathrm{ml}[19]$.

\section{Schinu sterebinthifolius (Brazillian pepper)}

Schinus terebinthifolius Raddiis the scientific name for brazillian pepper. It is grown in Brazil and America, and belongs to the Anacardiaceae family [8]. The main constituents of its essential oil include sylvestrene, $\alpha$-pinene, $\delta$-3-carene germacrene $D, \beta$-myrcene and isoterpinolene [20]. In a study conducted by Cazaux et al. [21]. Brazillian pepper essential oil was evaluated for its anticancer activities against human breast cancer cells (MCF-7). Brazillian Pepper essential oil had IC50 value of $47 \pm 9 \mathrm{mg} / \mathrm{L}$, and showed antioxidant activity using ABTS assay, with an IC50 value of $24 \pm 0.8 \mathrm{mg} / \mathrm{L}$ [21].

\section{Nigella sativa (Black cumin)}

Scientifically known as Nigella sativa, black cumin is native to southwest Asia and is also found in Africa [8]. It belongs to the Ranunculaceae family. Recent studies revealed that thymoquinone, (constituent of Nigella sativa), gives protection against doxorubicin-induced cardiotoxicity. Thymoquinone can act as a booster for the anti-cancer effect of doxorubicin, (chemotherapy agent), in some cancer cell lines [22].

Barek et al. (2007), worked on P815 murine mastocytoma cell line, Vero kidney carcinoma cell lines of monkeys, BSR kidney carcinoma cell lines of hamsters and ICO1 sheep heart carcinoma cell lines and treated them with $1 \%$ (v/v) Black cumin essential oil. IC50 values obtained for these cell lines were 78.26 $\pm 6.50 \mathrm{n}$ lM of DOX, $86.30 \pm 8.87 \mathrm{n}$ lM of DOX, $45.23 \pm 3.80 \mathrm{n} \mathrm{lM}$ of DOX and 82.25 $\pm 6.26 \mathrm{n} \mathrm{IM}$ of DOX, respectively [22].

In a study conducted by Sheddi et al. [23], human lung cancer cells were exposed to Nigella sativa essential oil and cell viability was measured by NRU assay. Cell viability decreased and the cell morphology of A-549 was altered on exposure to Nigella sativa essential oil concentrations of $0.1 \mathrm{mg} / \mathrm{ml}$ and more, for 24 hours was found to be cytotoxic. The decrease in cell viability at 1 $\mathrm{mg} / \mathrm{ml}$ of NSO was found to be $13 \%$ by using MTT assay. A-549 human lung cancer cells exposed to $0.25,0.5$ and $1 \mathrm{mg} / \mathrm{ml}$ of Nigella sativa essential oil lost their characteristic morphology and were smaller in size. This showed Nigella sativa essential oil helps in reducing human lung cancer cells viability $[23,24]$.

\section{Conclusion}

It can be suggested from the above that the ingredients selected for our diet have been chosen intelligently as most of them have therapeutic potentials. All over world the diet and daily use components have potential to treat many diseases. The above mentioned from different countries not only are used for the above said anti cancer activities but also have many of the traditional and medicinal values. As we need more options for anti cancer drugs these traditionally used herbs are being explored if they can work as better anticancer drugs. The details available suggest that these herbs also have similar target molecules and pathways as modern day's medicine. It's high time to work upon the mechanism of action and other aspect of them to develop them as anticancer drugs.

\section{Reference}

1. M Boskabady, M Shafei, Z Saberi, S Amini (2011) Pharmacological Effects of Rosa Damascena. Iranian J Basic Med Sci 14(4): 295-307.

2. H Knapp, M Straubinger, S Fornari, N Oka, N Watanabe, P Winterhalter (1998) ( S )-3,7-Dimethyl-5-octene-1,7-diol and Related Oxygenated Monoterpenoids from Petals of Rosa damascena Mill. Journal of Agricultural and Food Chemistry 46(5): 1966-1972.

3. A Schieber, K Mihalev, N Berardini, P Mollov, R Carle (2005) “Flavonol Glycosides from Distilled Petals of Rosa damascena Mill. Z Naturforsch C 60(5-6): 379-384.

4. E Kwon, D Lee, H Lee, D Kim, N Baek, et al. (2010) Flavonoids from the Buds of Rosa damascene Inhibit the Activity of 3-Hydroxy-3- 


\section{Cancer Therapy \& Oncology International Journal}

methylglutaryl-coenzyme A Reductase and Angiotensin I-Converting Enzyme. Journal of Agricultural and Food Chemistry 58(2): 882-886.

5. M Hotta (2017) Carvacrol, A Component Of Thyme Oil, Activates PPAR and Suppresses COX-2 Expression. The Journal of Lipid Research 51(2009): 132-139.

6. E Abdel-Hameed, S Bazaid, H Hagag (2015) Chemical characterization of Rosa damascena Miller var. trigintipetala Dieck essential oil and its in vitro genotoxic and cytotoxic properties. Journal of Essential Oil Research 28(2): 121-129.

7. Y Zu, H Yu, L Liang, Y Fu, T Efferth, et al. (2010) Activities of Ten Essential Oils towards Propioni bacterium acnes and PC-3, A-549 and MCF-7 Cancer Cells. Molecules 15(5): 3200-3210.

8. I Benzie, S Wachtel-Galor (2011) Herbal medicine. (1 $1^{\text {st }}$ edn.) Boca Raton: CRC Press.

9. R Cohen, K Ek, C Pan (2002) Complementary and Alternative Medicine (CAM) Use by Older Adults: A Comparison of Self-Report and Physician Chart Documentation. J Gerontol A Biol Sci Med Sci 57(4): 223-227.

10. Y Liu, R Whelan, B Pattnaik, K Ludwig (2012) Terpenoids from Zingiber officinale (Ginger) Induce Apoptosis in Endometrial Cancer Cells through the Activation of p53. PLoS ONE 7(12): 53178.

11. J Manosroi, P Dhumtanom, A Manosroi (2006) Anti-proliferative activity of essential oil extracted from Thai medicinal plants on $\mathrm{KB}$ and P388 cell lines. Cancer Letters 235(1): 114-120.

12. P Kathirvel, S Ravi (2012) Chemical composition of the essentia oil from basil (Ocimum basilicum Linn.) and its in vitro cytotoxicity against HeLa and HEp-2 human cancer cell lines and NIH 3T3 mouse embryonic fibroblasts. Natural Product Research 26(12): 1112-1118.

13. P Oliveira, J Alves, J Damasceno, R Oliveira, H Dias, et al. (2015) Cytotoxicity screening of essential oils in cancer cell lines. Revista brasileira de Farmacognosia 25(2): 183-188.

14. G Mahmoud (2013) Biological effects, antioxidant and anticance activities of marigold and basil essential oils. Journal of Medicinal Plants Research 7(10): 561-572.
15. M Özcan, J Chalchat (2008) "Chemical composition and antifungal activity of rosemary (Rosmarinus officinalis L.) oil from Turkey". International Journal of Food Sciences and Nutrition 59(7-8): 691-698.

16. W Wang, N Li, M Luo, Y Zu, T Efferth (2012) “Antibacterial Activity and Anticancer Activity of Rosmarinus officinalis L. Essential Oil Compared to That of Its Main Components". Molecules 17(12): 2704-2713.

17. P Sharma, D Mondhe, S Muthiah, H Pal, A Shahi, et al. (2009) "Anticancer activity of an essential oil from Cymbopogon flexuosus". ChemicoBiological Interactions 179(2-3): 160-168.

18. A Kumar, F Malik, S Bhushan, V Sethi, A Shahi, et al. (2008) "An essential oil and its major constituent isointermedeol induce apoptosis by increased expression of mitochondrial cytochrome $\mathrm{c}$ and apical death receptors in human leukaemia HL-60 cells". Chemico-Biological Interactions 171(3): 332-347.

19. N Dubey, N Kishore, S Lee (1997) "Cytotoxicity of the essential oil of Cymbopogon citratus and Ocimum gratissimum”. Indian J Pharm Sci 59: 263-264.

20. A Silva, D Almeida, S Ronchi, A Bento, R Scherer, et al. (2010) “The essential oil of Brazilian pepper, Schinus terebinthifolia Raddi in larval control of Stegomyia aegypti (Linnaeus, 1762)". Parasites \& Vectors 3(1): 79.

21. H Bendaoud, M Romdhane, J Souchard, S Cazaux, J Bouajila (2010) "Chemical Composition and Anticancer and Antioxidant Activities of SchinusMolle L. and Schinus terebinthifolius Raddi Berries Essential Oils". Journal of Food Science 75(6): 466-472.

22. K Effenberger-Neidnicht, R Schobert (2010) “Combinatorial effects of thymoquinone on the anti-cancer activity of doxorubicin". Cancer Chemotherapy and Pharmacology 67(4): 867-874.

23. E Al-Sheddi, N Farshori, M Al-Oqail, J Musarrat, A Al-Khedhairy, et al (2014) "Cytotoxicity of Nigella Sativa Seed Oil and Extract Against Human Lung Cancer Cell Line”. Asian Pac J Cancer Prev 15(2): 983-987.

24. L Ait Mbarek, H Ait Mouse, N Elabbadi, M Bensalah, A Gamouh, et al. (2007) "Anti-tumor properties of blackseed (Nigella sativa L.) extracts". Braz J Med Biol Res 40(6): 839-847.

\section{Your next submission with Juniper Publishers} will reach you the below assets

- Quality Editorial service

Swift Peer Review

- Reprints availability

- E-prints Service

- Manuscript Podcast for convenient understanding

- Global attainment for your research

- Manuscript accessibility in different formats

( Pdf, E-pub, Full Text, Audio)

- Unceasing customer service

Track the below URL for one-step submission https://juniperpublishers.com/online-submission.php 